Spring 1995

\title{
Making-up the Toraja? The Appropriation of Tourism, Anthropology, and Museums for Politics in Upland Sulawesi, Indonesia
}

Kathleen M. Adams

Loyola University Chicago, kadams@luc.edu

Follow this and additional works at: https://ecommons.luc.edu/anthropology_facpubs

Part of the Anthropology Commons

\section{Recommended Citation}

Adams, K. (1995). "Making-up the Toraja? The Appropriation of Tourism, Anthropology, and Museums for Politics in Upland Sulawesi, Indonesia." Ethnology, 34(2), p. 143-153.

This Article is brought to you for free and open access by the Faculty Publications and Other Works by Department at Loyola eCommons. It has been accepted for inclusion in Anthropology: Faculty Publications and Other Works by an authorized administrator of Loyola eCommons. For more information, please contact ecommons@luc.edu. cc) (i) $\ominus$

This work is licensed under a Creative Commons Attribution-Noncommercial-No Derivative Works 3.0 License. (c) University of Pittsburgh, Department of Anthropology, 1995. 


\section{MAKING-UP THE TORAJA? THE APPROPRIATION OF TOURISM, ANTHROPOLOGY, AND MUSEUMS FOR POLITICS IN UPLAND SULAWESI, INDONESIA ${ }^{1}$}

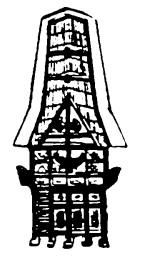

Kathleen M. Adams

Loyola University of Chicago

Over the past fifteen years anthropologists studying ethnic phenomena have rejected older conceptions of cultural identity and tradition as stable, bounded realities born out of the past, turning instead to embrace a notion of cultural identity as a dynamic, ongoing process of negotiation and political contestation. As the essays in Hobsbawm and Ranger's volume (1983) as well as recent works by Keesing (1989), Linnekin (1983), Clifford (1988), Handler (1988), and others have shown, traditional identities do not simply draw on the wellsprings of the past but are infused with the politics of the present.

Starting from the notion that tradition is a political construction, yet anchored in the concern with the politics of culture and identity, this essay examines how a hinterland group of Indonesian people, much scrutinized by both tourists and anthropologists, is now drawing on and manipulating these very global powers for its own ends. While much has been written on the ways in which culture is manipulated for the consumption of outsiders (cf. MacCannell 1973; Greenwood 1989 [1977]; Cohen 1988), the focus here is on the ways in which outsiders are coopted for local power contests. As this case suggests, no longer can anthropologists and tourists imagine themselves as peripheral to local constructions of identity and power. Moreover, the literature on ethnic tourism tends to assume that tourism inevitably brings a loss of agency to local peoples. This article proposes problematizing such global assumptions. As the Toraja material suggests, in the face of tourism (and anthropological celebrity), Torajans continue to be active strategists and ingenious cultural politicians.

In the following pages I explore how, in the present context of tourism, nationalism, Christianization, and anthropological study, Torajan ideas about the ancestral authority of the elite are actively being re-evaluated and contested by lowerranking members of society. While those without claims to aristocratic status struggle to propagate their own versions of Torajan culture (versions which challenge the elites' sanitized representations of “Toraja with make-up"), Torajan aristocrats engage in a variety of enterprises designed to bolster their own local pre-eminence. In this contest, anthropology and tourism figure prominently in both nobles' and commoners' interested versions of culture and status.

Today, politically savvy Torajans recognize anthropology and tourism's potential for validating and amplifying particular versions of culture. As illustration, this essay describes several cases in which anthropologists and tourists are drawn into the

ETHNOLOGY vol. 34 no. 2, Spring 1995, pp. 143-53.

ETHNOLOGY, c/o Department of Anthropology, The University of Pittsburgh, Pittsburgh PA 15260 USA

Copyright 1995 The University of Pittsburgh. All rights reserved. 
authority-building projects of both elites and commoners, and explores some of the ironies inherent to these local battles over the representation of cultural traditions.

\section{THE SA'DAN TORAJA: PAST AND PRESENT}

In a nation of 185 million, the Sa'dan Toraja people of upland Sulawesi, with whom I conducted over two years of field research in 1984-1985, 1987, and 1991, are a small minority of approximately 350,000 . They are marginalized by island geography, religion, and a diffuse power structure. The Toraja's closest neighbors are the lowland Islamicized Makassarese and Buginese peoples, the dominant ethnic groups of the region. In contrast to the highly developed kingdoms of these neighboring peoples, the Toraja never had a centralized political kingdom. In the past, these swidden and wet-rice agriculturalists lived in scattered mountain-top settlements, maintaining social ties through an elaborate system of ritual exchanges (Nooy-Palm 1979). Only with the arrival of the Dutch colonial forces in 1906 were the Sa'dan Toraja united under a single political authority.

Several years after the Dutch annexation of the highlands, missionaries from the Dutch Reformed Church began proselytizing amongst the Toraja. ${ }^{2}$ Conversion was initially slow but gathered tremendous momentum in the 1950s and 1960s. This growth can be attributed partially to the effects of Christian schools in the highlands and partially to the newly independent Indonesian government's policy of encouraging animistic groups to abandon their ways of the past and join the folds of a world religion. Today, over 80 per cent of the Sa'dan Toraja are Christians and the Church is central to the lives and identities of many highlanders. With over 90 per cent of Indonesia's inhabitants describing themselves as Muslims, Torajans are self-conscious of their identity as a Christian minority.

Toraja society is hierarchically organized on the basis of age, descent, wealth, and occupation. In precolonial times there were three broad social tiers: the aristocracy, commoners, and slaves. ${ }^{3}$ Status was determined by birth, although economic aptitude or failure facilitated some degree of social mobility. Slavery is now outlawed in Indonesia and rank is a sensitive topic in Tana Toraja.

International and domestic tourism to the Toraja highlands is a relatively recent phenomenon. During the 1950s and early 1960s poor roads and Muslim guerrilla movements made travel in South Sulawesi a risky endeavor. However, in the late 1960s Indonesia's President Suharto began actively encouraging the development of tourism as an industry. After initially concentrating on expanding tourism in Bali, Java, and Sumatra, in 1974 the government began vigorously cultivating and promoting Tana Toraja and other outer island destinations (Spillane 1987). Spotlighting colorful Torajan funeral rituals, eerily carved effigies of the dead, and scenic traditional villages, the touristic marketing of the Toraja was extremely successful. Whereas in 1973 only 422 foreigners voyaged to the highlands, by 1991 over 215,000 foreign and domestic tourists were visiting the region annually. 
Just as tourism in Tana Toraja began to develop rapidly in the 1970s and 1980s, so did anthropological research in the highlands. Whereas only three anthropologists conducted extended research on Torajan culture prior to the mid-1970s (Crystal 1971, 1974, 1989; Koubi 1982; Nooy-Palm 1975, 1979), by the early 1990s many anthropologists and graduate students had studied Torajan culture from almost every imaginable angle (Adams 1984, 1988, 1991, 1993; Coville 1988, 1989; Hollan 1984, 1988; Hollan and Wellenkamp 1994; Tangdilintin 1981; Volkman 1985, 1990; Waterson 1981, 1984; Wellenkamp 1984, 1988; Yamashita 1988).

The tales of tourists and the writings of anthropologists have made Torajans into international celebrities, their culture an entity to be studied, dissected, photographed, and packaged for export (Adams 1990a). Today's Torajans are inundated with outsider images of their culture. Glossy travel brochures herald the Toraja as "Heavenly Kings" living in a "land where time stands still." Indonesian television shows highlight traditionally dressed Toraja singers perched on ornately carved Toraja rice barns. Tee-shirts are emblazoned with sketches of “Torajan Warriors.” And postcards sold as far away as Jakarta feature photographs of Toraja tombs and water buffalo sacrifices. There even are videos in Indonesian and English documenting the "Death Ceremony of the Torajans" for sale in local shops. In short, contemporary Torajans are not only ethnically self-conscious, but avid consumers, manipulators, and critics of the ethnographic and touristic images of their culture.

\section{TORAJA WITH MAKE-UP}

My introduction to the politics of identity in Tana Toraja began on my third day in the field. Needing a map of the area, I was pointed by several young aspiring Torajan guides in the direction of a small general store near the market. On entering the store, it immediately became clear that the shopowner had been told who I was. Greeting me warmly, he asked me to sit and talk with him and his friend about anthropology in Tana Toraja. His companion, an articulate intellectual in his fifties, introduced himself as the grandson of Tammu, the co-author of the TorajanIndonesian dictionary which I carried in my bag. As the shopowner gestured for his wife to bring some coffee and rice sweets, Tammu's grandson leaned forward and began advising me about what should be the focus of my research. In a serious tone he counseled:

As an anthropologist, you should write a book about the real Torajan identity and history, both the good and the bad. I mean Torajan identity that is authentic and true. I don't like to see Torajan identity presented with make-up to conceal its flaws. These days some people use their writings to cover up the negative, embarrassing things-like slaves-and magnify the positive things. We need a new book to correct all of these portraits of Torajans with make-up. . . .

While sipping coffee, I considered his depiction of Torajans with make-up. Over the previous half dozen years the Toraja people had been abruptly thrust into the spotlight. Tana Toraja Regency had just been declared the touristic "prima donna of 
South Sulawesi" by the Indonesian Director General of Tourism. Not only were tourists flocking to the highlands, but so were Indonesian, American, French, and Dutch anthropologists. Clearly, the growing mounds of anthropological and touristic literature on the Toraja had caught this man's attention. He resumed his commentary:

My grandfather wrote a book that represents the authentic Toraja history I'm talking about. ${ }^{4}$. . . His book tells about the different kinds of slaves [kaunan] and even explains the rituals which allow slaves to marry nobles [puangs] and not have their children considered slaves . . . how many buffalo they have to sacrifice and all that. But nowadays slaves are simply marrying nobles and declaring their children nobles. That's not right. The more time passes, the more nobles we get!

Shaking his head disapprovingly about all the "false nobles" in Toraja, he pointed to the ubiquitous touristic portrayal of Torajans as "Heavenly Kings" as one of several sources for such "unauthentic" notions of identity:

Many people here like to say our name means kingly people because it makes them seem more majestic. But this invented meaning is like a balloon; you start out with a small piece of rubber and, if you keep inflating it, it will finally burst and have no value at all. . . These days Torajan identity is being inflated and soon it will burst. That's why we must pursue the true Toraja, the Toraja without make-up.

Clearly, this aristocrat was deeply disturbed that commoners had been particularly quick to embrace the false etymology promoted in the tourist brochures of Toraja as "Heavenly Kings" or "Kingly People." Indeed, while in the field I frequently overheard young aspiring Torajan guides of non-noble descent repeat this contrived etymology to visitors. On other occasions, as well, it appeared that many of these lower-ranking cultural interpreters were bypassing explanations of Torajan traditions that stressed rank, preferring instead to communicate to tourists how their art and rituals conveyed Torajans' traditional respect for nature and death. For instance, these younger non-noble guides tended to reject the rank-related explanations of carved Torajan ancestral house facades that were popular among the nobility (see Adams 1988). Rather, many of these lower-ranking youths and guides stressed how the abstract carvings on the house facades attested to Torajans' veneration of nature.

When, several years later, I reflected on Tammu's grandson's urgings to write a book combatting the inflated Torajan identity, his emphasis on highlighting traditional status distinctions resonated with remarks made by other Torajan elites. Almost all of the elites I knew voiced concerns that they were no longer as esteemed as they had once been. Anxiety about the erosion of hereditary rank distinctions figured prominently in the narratives of Torajan elites and directed much of their social and political activity.

While Tammu's grandson cited touristic and anthropological imagery as a key source of the erosion of meaningful rank distinctions, other nobles attributed it to two decades of wage labor opportunities outside the highlands, which offered lowerranking Torajans new avenues to gain wealth (and hence authority). ${ }^{6}$ Still other elites identified competing systems of authority, such as Christianity and nationalism, as 
the sources of their own crises of authority. ${ }^{7}$ In short, they all recognized that in various ways this discourse with the wider world was not only prompting lowerranking Torajans to rethink the traditional local hierarchy, but facilitating a flattening of indigenous rank distinctions.

It is clear to me now that many Torajan elite were attempting to solidify their local authority by invoking these very forces that threatened them. In essence, these Torajans were no longer simply relying on the authority of adat (tradition) but were actively engaged in drawing on the new sources of authority to bolster their elite identities.

\section{ANCHORING ANCESTRAL AUTHORITY: TOURISM AND ANTHROPOLOGY}

This article explores how one aristocratic Torajan has drawn on the new arenas of tourism and anthropology to bolster his family's authoritative status. ${ }^{8}$ This man, whom I will call $\mathrm{Ne}$ ' Duma, was a wealthy landowner, a leader of the Toraja Protestant Church, and had once served as a legislative representative of Tana Toraja Regency. By the 1980s he had already established himself as an acclaimed and respected authority on Torajan tradition. Upon my arrival in 1984, when it became known that I was interested in working in Ne' Duma's district of Tana Toraja, a local government official insisted that I live with Ne'Duma and his family where, as he phrased it, "all the researchers go to study." As I later discovered, this government official was an adopted son of Ne' Duma. By steering me and others to study with $\mathrm{Ne}$ ' Duma, he was, in essence, furthering $\mathrm{Ne}$ ' Duma's status as an authority.

On my third evening in Ne' Duma's household, my host announced that we would begin my "lessons." Excusing myself to dig out my list of carefully compiled questions, I returned to find Ne' Duma absorbedly drawing in my notebook. Pushing aside my questions, he gestured to his drawing and announced, "This is where we start-get out your tape recorder, this is what's important." There in my notebook, he had sketched an elaborate kinship chart stretching back some 25 generations to the gods who were said to have descended on the mountain peak looming above the village. Except that his male and female symbols were reversed, in every way his genealogical chart could have qualified for an anthropology textbook. Over the next few weeks Ne' Duma recounted with verve the deeds of his deified ancestors, offering me a fundamental, albeit implicit, lesson on his ancestral claims to authority.

Bolstering their ancestral claims to authority was a central concern for $\mathrm{Ne}^{\prime}$ Duma and his family. My identity as an anthropologist was soon drawn into this process of authority-building. When local visitors stopped by the house, Ne' Duma's wife would quickly introduce me as the American anthropologist who had come to study with $\mathrm{Ne}$ ' Duma and who would eventually write a book about them. Before long, other elite leaders in the village were suggesting I drop by and interview them as well. As with $\mathrm{Ne}$ ' Duma, these interviews also tended to begin with a genealogical accounting of their ancestral authority and their links to celebrated ancestral houses (tongkonan). 
Several of these older nobles described with great animation the anthropology books they had seen featuring the nobles of the southern realms of Tana Toraja or highlighting aristocrats from the northern Sesean region. Repeatedly, these elite acquaintances urged me to include their own accounts in my book.

As I gradually began to realize, Ne' Duma and his aristocratic friends envisioned me and the book they imagined I would write as one of several new avenues for shoring up their local authority. Recognizing the power of print, it seemed they feared their own voices of authority would be muted without a book of their own. My awareness of this crystallized when a rival aristocratic family from another Torajan district visited our village and my Torajan hosts introduced me as "their anthropologist" who had come to study with Ne' Duma. To this, the visitors responded that they, too, had an anthropologist live with them and write about them. After these guests departed, my Torajan family disparaged the other anthropologist's understanding of Torajan culture and proclaimed that my "book" would be "much bigger and better." After all, I was studying with $\mathrm{Ne}$ ' Duma.

My service as a new-genre marker of Ne' Duma's authority was further evinced by my host family's reaction when tour guides added me to their itinerary of touristic objects. Following a few happenstance encounters with tour groups, guides soon began to recognize that, for tourists, my very presence in the field reified their sense of being in a truly remote area, where ancient culture worthy of anthropological study was still very much alive. Accordingly, tour guides ushering their groups through the village began stopping at my host's home to introduce me to their guests. My fears that this would exhaust the patience of Ne' Duma's family were unfounded. Quite the contrary, my hosts appeared delighted by the visits and would rush to prepare tea for the tourists. As they served the tea, they would check to make sure the guides had told their guests that I was there studying Toraja culture from $\mathrm{Ne}^{\text {' }}$ Duma. In short, for them I was not a marker of the exotic but a new kind of marker of Ne' Duma's ancestral authority. Moreover, for my hosts I represented a convenient opportunity to amplify Ne' Duma's status as a celebrated elder to novel foreign audiences.

\section{THE POLITICS OF NAMING TOURIST DESTINATIONS}

Not only were some nobles turning to anthropologists as a new avenue for bolstering their pre-eminence, many clearly were seeking to anchor their ancestral authority in the realm of tourism planning as well. Ironically, tourism was the very arena that had hastened the dilution of their traditional symbols of aristocratic affiliation and power. For tourism, in highlighting what were once symbols of elite authority (such as ornately carved ancestral houses and elaborate funerals), has for many Torajans broadened these symbols into markers of ethnic affiliation regardless of rank (Adams 1990b).

While Ne' Duma never articulated this dimension of his strategy in our discussions, after his death his son shared Ne' Duma's tactics with me. He explained 
that Ne' Duma had been anxiously observing the erosion of the prestige of nobles in his area (known as Kesu') ever since the government seat was established in the southern city of Makale, near the Sangalla adat (custom) region of Tana Toraja. As Ne' Duma saw it, Sangalla nobles and Sangalla adat were overshadowing those of the Kesu' adat area. Ne' Duma's misgivings cemented in 1950 when, following independence, the subdistricts of Tana Toraja Regency were formally established: a Sangalla District (kecamatan) was delineated, but there were no provisions made for a Kesu' District. Ne' Duma recognized that with this new political geography, the name Kesu' would be lost, and with it the authority of the Kesu' nobles.

In the early stages of tourism development Ne' Duma saw his opportunity to ensure that the Kesu' name and its prestige lived on. Drawing on his authority as an elected politician, aristocratic leader, and Church elder, Ne' Duma lobbied local government authorities to declare his hamlet the first official "tourist object." Lauding the beauty of the setting, the large cluster of carved houses, and ease of access, Ne' Duma's campaign was successful and he named the newly declared tourist locale Ke'te' Kesu'. His son speculated that if Ne' Duma had not the foresight to give the tourist destination the appellation Ke'te' Kesu', quite probably the name Kesu' would have little meaning today, and Kesu' nobles would play only a minor role in local politics. Due to Ne' Duma's clever promotion of Ke'te' Kesu' as a tourist site, however, not only ordinary tourists but every Indonesian government official passing through Tana Toraja visits Ke'te' Kesu'. While touring the village, these officials would invariably encounter $\mathrm{Ne}^{\prime}$ Duma or members of his family and would hear their version of Torajan history.

$\mathrm{Ne}$ ' Duma's situation as reigning noble at the first tourist object cemented his position of authority in the new era of national politics and tourism. After successfully enshrining the name Kesu' on the touristic map of Tana Toraja, Ne' Duma wasted no time in producing written histories of tongkonan Kesu' and in presenting papers at tourism seminars on the historical significance of Kesu', his adat region. By the mid-1980s, Ne' Duma was one of the key lecturers at training sessions for local tour guides. While not all guides echoed Ne' Duma's aristocratic genealogy of celestial ancestry to their tourists, ${ }^{9}$ they all brought their charges to Ke'te' Kesu', where souvenirs purchased from Ne' Duma's family further augmented the family's wealth. In sum, Ne' Duma's strategy of embracing tourism to bolster his status, in tandem with his activities in the other new arenas of authority (the Christian Church and the national government), was successful. In fact, in 1985, he was ceremonially recognized as the "founding father" of Tana Toraja by Indonesian government officials. Moreover, after Ne' Duma died in 1986, Indonesian dignitaries who had met him on prior trips to the highlands returned for his funeral, further enhancing his family's local status.

It is noteworthy that Ne' Duma's grandfather employed a similar strategy in 1919 when he sensed that his authority was being overshadowed by Dutch colonialism. Recognizing that the Dutch were conferring authority on the nobles located nearest their colonial headquarters in the valley, Ne' Duma's grandfather had his ancestral 
house and seat of his authority (known as tongkonan Kesu') relocated from its remote site atop a mountain to the valley, clustering it with several other ancestral family houses. ${ }^{10}$ The move, completed in 1927, proved to be a successful scheme for currying local authority under colonialism.

\section{ENSHRINING ANCESTRAL AUTHORITY: TORAJA MUSEUMS}

Much has been written about the emergence of European museums and their ties to the display of elite power (e.g., Alexander 1979; Greenblatt 1991). In the Renaissance, a ruler's glory and mastery of the world were communicated and reinforced in the visual display of his collections. Today, in the context of tourism, Torajan elite are discovering and borrowing the Western institution of museums with what appear to be similar motives.

The first Torajan museum was opened by a celebrated regal family in the Sangalla district. This museum, which housed family heirlooms such as a golden kris, treasured textiles, and carved wooden bowls and spoons, was soon added to the touristic map of Tana Toraja. Given its location off the main tourist track and its unpredictable hours, it was not heavily visited. Torajans, however, were well aware of its existence and, for Ne' Duma's family, this museum was a reminder of old rivalries and ambivalences between Kesu' and Sangalla elites. On several occasions $\mathrm{Ne}$ ' Duma's wife and other family members commented on the need for a museum of their own.

When I returned to the field in 1989, Ne' Duma's family had created a museum in the heart of Ke'te' Kesu'. Located in the family's ornately carved ancestral house (tongkonan), the museum featured not only cooking and agricultural implements, but a display of material markers of wealth and power such as prized ritual textiles, knives, and traditional eating utensils specially designed for nobles. Aged carvings and a traditional warrior's outfit rounded out the display. Significantly, the family chose to name the museum for a much beloved deceased sister of $\mathrm{Ne}$ ' Duma, an unmarried antique dealer without children of her own. Her photograph and life-sized carved image (tau-tau) presided over the museum. Ne' Duma's family envisioned the museum as a way of honoring and perpetuating her memory.

Moreover, in establishing the museum, Ne' Duma's family was not only celebrating the memory of this woman but was staking its own new-genre claim to continued glory, particularly vis-à-vis their more prestigious Sangalla rivals. On my last visit to Tana Toraja, several family members pointedly remarked that many more tourists passed through their museum than the Sangalla museum and reminded me of how the Sangalla museum was always locked up. Here again, we find Torajan elites co-opting imported institutions for local contests of power. In this case, Ne' Duma's family saw the number of tourist visitors as their measure of success. 


\section{CONCLUSION}

Today's Torajan elites are drawing on new arenas of authority to bolster their eroding local status. In an ironic yet ingenious fashion, they are anchoring their ancestral authority in precisely the same phenomena that originally fueled challenges to their local pre-eminence. The Torajan elites' appropriation of tourism and anthropology underscores Hobsbawm and Ranger's (1983), Linnekin's (1983, 1992), Keesing's (1989), and others' observations concerning the continuous reinvention of tradition. In the Toraja case, the tradition of aristocratic authority is infused with the touristic and anthropological politics of the present. Yet, while the invention of tradition is related to the politics of the present, that present is equally infused with the past.

Moreover, for the Toraja, not only their own culture but the anthropologists and tourists they attract all serve as political symbols that can be drawn upon to enhance their position vis-à-vis their local rivals. While the Torajan elite cannot control the cash economy, they are sophisticated in their ability to manipulate global powers and institutions locally (such as tourism, anthropology, and museums), for their own ends in attempts to buttress their traditional authority. As the Toraja cases teach, anthropologists would do well to remember that our own positions in fieldwork situations are invariably entrenched in local discourses of tradition and power politics.

\section{EPILOGUE}

It is fitting to end with Ne' Duma's own final resting place. Approximately six months after his death in 1986, his family staged an elaborate pageantry-filled funeral that attracted thousands of guests, tourists, and dignitaries ${ }^{11}{ }^{1}$ Following the funeral, $\mathrm{Ne}$ ' Duma's body was installed in an enormous, lavishly carved cement tomb designed by his son. A life-sized, strikingly realistic effigy (tau-tau) of Ne' Duma adorns the front of the tomb. Encased in glass and looming ten feet high, the effigy dominates the vista. The tomb and effigy are the first objects tourists see as they descend the Ke'te' Kesu' village path to view the traditional graves. Today, guides regularly pause at the base of Ne' Duma's tomb to recount his life story and exploits. Quite fittingly, although deceased for over eight years, Ne' Duma lives on in all of his glory, narrated every day by guides to tourists.

\section{NOTES}

1. I am grateful to the NEH seminar participants, particularly Lamont Lindstrom and Geoffrey White, for illuminating issues central to this article. Paul Breidenbach and Greg LeRoy gave me useful comments on an earlier draft which was presented at the 1993 annual meeting of the American Anthropological Association. A Fulbright Fellowship and grants from the University of Washington (Gowen) and Beloit College (Hewlett-Mellon) funded research. I am also grateful to the late Ne' Duma (pseudonym), who taught me much about Toraja culture and political navigation. 
2. See Bigalke (1981) for a delineation of the historical role of the Dutch Reformed Church in fortifying Torajan ethnic consciousness.

3. For a full description of rank in contemporary Tana Toraja, see Adams (1988:51-60), Crystal (1971), and Volkman (1985).

4. The "authenticity" of his grandfather's book is partially culled from his experience with a Dutch controller with whom he wrote the dictionary. Interaction with outsiders and exposure to their writings provide material for reflection about autochthonous identity.

5. See Adams (1984) for a discussion of the evolution of this false etymology invented by tourism promoters.

6. Volkman (1990) describes how Torajan wage labor migration has enabled the inflation of Torajan rituals.

7. For a more detailed discussion of these themes, see Adams (n.d.).

8. See Adams (n.d.) for an exploration of the interplay between nationalist rhetoric and aristocratic Torajan strategies for maintaining authority.

9. In fact, many of the young guides were predominantly commoners or descendants of slaves and contested touristic explanations that stressed rank distinctions (Adams 1988).

10. Some sources suggest that the move was not voluntary but forced. Whatever the case, the very telling of this version of the story suggests a certain political ingenuity.

11. For an elaboration on how Ne' Duma's funeral exemplifies a reconceptualization of ritual performance in the context of a growing discourse with the wider world, see Adams (1993).

\section{BIBLIOGRAPHY}

Adams, K. M. 1984. Come to Tana Toraja, "Land of the Heavenly Kings": Travel Agents as Brokers in Ethnicity. Annals of Tourism Research 11(3):469-85.

1988. Carving a New Identity: Ethnic and Artistic Change in Tana Toraja. Ph.D. dissertation, University of Washington. Seattle.

1990a. Cultural Commoditization in Tana Toraja, Indonesia. Cultural Survival Quarterly 14:31-34.

1990b. More than an Icon of Identity: Torajan Art as Ethnic Weapon. Paper presented at the University of Washington, Jackson School for International Studies Program on Race and Ethnic Relations.

1991. Distant Encounters: Travel Literature and the Shifting Image of the Toraja of South Sulawesi, Indonesia. Terra Incognitae 23:1-12.

1993. Club Dead, Not Club Med: Staging Death in Contemporary Tana Toraja (Indonesia). Southeast Asian Journal of Social Science 21(2):62-72.

n.d. Constructing and Contesting Chiefly Authority in Contemporary Tana Toraja. MS. Chiefs Today, eds. G. White and L. Lindstrom. Stanford. Originally presented at the 1993 symposium "Chiefs Today," Association for Social Anthropology in Oceania Annual Meeting, Kona.

Alexander, E. P. 1979. Museums in Motion: An Introduction to the History and Functions of Museums. Nashville.

Bigalke, T. 1981. A Social History of Tana Toraja 1870-1965. Ph.D. dissertation, University of Wisconsin. Madison.

Clifford, J. 1988. The Predicament of Culture: Twentieth-Century Ethnography, Literature, and Art. Cambridge MA.

Cohen, E. 1988. Authenticity and Commoditization in Tourism. Annals of Tourism Research 15(3):37186.

Coville, E. 1988. "A Single Word Brings to Life": The Maro Ritual in Tana Toraja (Indonesia). Ph.D. dissertation, University of Chicago. 
1989. Centripetal Ritual in a Decentered World: Changing Maro Performances in Tana Toraja. Changing Lives, Changing Rites: Ritual and Social Dynamics in Philippine and Indonesian Uplands, eds. S. Russell and C. Cunningham, pp. 103-31. Michigan Studies of South and Southeast Asia, Number 1. Ann Arbor.

Crystal, E. 1971. Toraja Town. Ph.D. dissertation, University of California. Berkeley.

1974. Cooking Pot Politics: A Toraja Village Study. Indonesia 18:119-51.

1989. Tourism in Toraja (Sulawesi, Indonesia). Hosts and Guests: The Anthropology of Tourism, ed. V. Smith, pp. 139-68. Philadelphia.

Greenblatt, S. 1991. Resonance and Wonder. Exhibiting Cultures: The Poetics and Politics of Museum Display, eds. I. Karp and S. Lavine, pp. 42-56. Washington DC.

Greenwood, D. 1989. (1977) Culture by the Pound: An Anthropological Perspective on Tourism as Cultural Commoditization. Hosts and Guests: The Anthropology of Tourism, ed. V. Smith, pp. 171-85. Philadelphia.

Handler, R. 1988. Nationalism and the Politics of Culture in Quebec. Madison.

Hobsbawm, E., and T. Ranger. 1983. The Invention of Tradition. Cambridge.

Hollan, D. 1984. Disruptive Behavior in a Toraja Community. Ph.D. dissertation, University of California. San Diego.

1988. Pockets Full of Mistakes: The Personal Consequences of Religious Change in a Toraja Community. Oceania 58(4):275-89.

Hollan, D. W., and J. C. Wellenkamp. 1994. Contentment and Suffering: Culture and Experience in Toraja. New York.

Keesing, R. 1989. Creating the Past: Custom and Identity in the Pacific. The Contemporary Pacific 1 \& 2:19-42.

Koubi, J. 1982. Rambu Solo': “La Fumee Descend”: Le Culte des Morts Chez les Toradja du Sud. Paris.

Linnekin, J. 1983. Defining Tradition: Variations on the Hawaiian Identity. American Ethnologist 10:241-52.

1992. On the Theory and Politics of Cultural Construction in the Pacific. Oceania 62:249-63.

MacCannell, D. 1973. Staged Authenticity: Arrangements of Social Space in Tourist Settings. American Journal of Sociology 79(3):589-603.

Nooy-Palm, H. 1975. Introduction to the Sa'dan Toraja People and their Country. Archipel 10:52-92. 1979. The Sa'dan Toraja: A Study of their Social Life and Religion, vol. 1. The Hague.

Spillane, J. J. 1987. Pariwisata Indonesia: Sejarah dan Prospeknya. Yogyakarta.

Tangdilintin, L. T. 1981. Toraja dan Kebudayannya. Tana Toraja.

Volkman, T. 1985. Feasts of Honor: Ritual and Change in the Toraja Highlands. Urbana and Chicago. 1990. Visions and Revisions: Toraja Culture and the Tourist Gaze. American Ethnologist 17(1):91-110.

Waterson, R. 1981. The Economic and Social Position of Women in Tana Toraja. Ph.D. dissertation, Cambridge University. 1984. Ritual and Belief Among the Sa'dan Toraja. Canterbury.

Wellenkamp, J. 1984. A Psychocultural Study of Loss and Death Among the Toraja. Ph.D. dissertation, University of California. San Diego.

1988. Notions of Grief and Catharsis Among the Toraja. American Ethnologist 15(3):486-500.

Yamashita, S. 1988. Girei no Seijigaku: Indonesia Toraja no Dotaiteki Minzokushi (Politics of Ritual Among the Toraja of Sulawesi, Indonesia). Tokyo. 